\title{
Gambaran Kebahagiaan Mustahik Di Lembaga Amil Zakat Pekanbaru
}

\author{
Ikhwanisifa $^{1}$, Reni Susanti ${ }^{2}$, Salmiyati $^{3}$ \\ ${ }^{1,2,3}$ Fakultas Psikologi Universitas Islam Negeri Sultan Syarif Kasim Riau \\ salmiyati@uin-suska.ac.id
}

\begin{abstract}
Abstrak
Kebahagiaan merupakan salah satu kondisi yang ingin dicapai setiap orang. Berbagai situasi kehidupan seperti sulitnya memenuhi kebutuhan hidup dan tidak harmonisnya relasi sosial kadangkala menghambat pencapaian kebahagiaan. Penelitian ini mengkaji bagaimana gambaran kebahagiaan pada para mustahik yang ada di Pekanbaru. Sampel penelitian berjumlah 180 orang, merupakan para mustahik yang mendapat bantuan dari lembaga amil zakat dan mengikuti program pendampingan/pemberdayaan di 3 lembaga amil zakat. Alat ukur kebahagiaan yang digunakan dalam penelitian ini dimodifikasi dari Oxford Happines Questionnaire (OHQ) yang dikembangkan oleh Argyle, Martin \& Crossland. Berdasarkan hasil analisis data ditemukan bahwa kebahagiaan para mustahik berada pada kategori tinggi. Selanjutnya hasil analisis one-way anova menemukan bahwa tidak terdapat perbedaan tingkat kebahagiaan para mustahik berdasarkan jenis bantuan yang diterima. Begitu pula halnya dengan jenis kelamin, usia, dan pekerjaan. Hal ini berarti bahwa para mustahik mempersepsikan kondisi kehidupannya secara positif sehingga mampu menerima dirinya, menunjukkan perasaan senang dan optimis, memiliki harga diri yang baik, serta meyakini kemampuannya dalam menghadapi kehidupannya masing-masing.
\end{abstract}

Kata kunci : kebahagiaan, mustahik, lembaga amil zakat

\begin{abstract}
Happiness is one of the conditions that everyone wants to achieve. Various life situations such as the difficulty of fulfilling life's needs and disharmony in social relations sometimes hinder the achievement of happiness. This research examines how the description of happiness in mustahik in Pekanbaru. The research sample consisted of 180 people, consisting of mustahik who received assistance from amil zakat institutions and participated in mentoring / empowerment programs at 3 amil zakat institutions. The happiness measurement tool used in this study was modified from the Oxford Happines Questionnaire (OHQ) developed by Argyle, Martin \& Crossland. Based on the results of data analysis, it was found that the happiness of the mustahiks was in the high category. Furthermore, the results of the one-way ANOVA analysis found that there was no difference in the happiness level of the mustahiks based on the type of assistance received. Likewise with gender, age and occupation. This means that the mustahik perceive their life conditions positively so that they are able to accept themselves, show feelings of joy and optimism, have good self-esteem, and believe in their ability to face their respective lives
\end{abstract}

Kewyord: Happiness, mustahik, amil zakat institutions 


\section{Pendahuluan}

Di Indonesia, jumlah penduduk dengan kategori miskin tercatat sebanyak 27,77 juta jiwa atau sekitar 10,64\% (BPS bulan Maret 2017). Data pada Inisiasi Zakat Indonesia yang merupakan salah satu lembaga amil zakat di Riau menampung 2500 penerima manfaat, dan sebagian besar diantaranya masuk dalam kategori fakir dan miskin. Adapun data di Rumah Zakat Cabang Riau pada tahun 2017 diketahui bahwa keluarga yang termasuk dalam kategori mustahik dan mendapat manfaat zakat sebanyak 725 orang.

Zakat adalah salah satu solusi dalam Islam untuk mengentaskan kemiskinan. Elzaky (2015) menjelaskan bahwasanya zakat termasuk ibadah yang dapat digunakan untuk mengurangi kesenjangan antara golongan kaya dan miskin serta meratakan kehidupan ekonomi di tengah masyarakat sehingga terwujud tradisi tolong-menolong. Zakat menjadi salah satu topik utama yang menjadi perhatian Islam, karena kemiskinan dan kefakiran berpeluang menghantarkan manusia jatuh peradabannya. Sebagaimana dinyatakan dalam hadits Nabi Muhammad SAW bahwa kefakiran itu mendekati pada kekufuran. Oleh karenanya kehadiran lembaga zakat diharapkan dapat menjauhkan hal tersebut dari para mustahik. penelitian Syaukat dkk (2016) menyimpulkan bahwa bantuan zakat memiliki dampak positif terhadap produktivitas mustahik.

Ataya (dalam Urif, Herwanti dan Huzaini 2018) juga menyatakan bahwa zakat yang diterima oleh para mustahik diharapkan mampu memberikan ketenangan, keamanan dan kesejahteraan hidup mustahik. Penyaluran zakat melalui lembaga amil zakat dilakukan melalui dua pola, yaitu konsumtif dan produktif. Program penyaluran zakat secara konsumtif diberikan kepada mustahiq melalui pemberian bantuan secara langsung seperti makanan, uang dan sebagainya, berbeda dengan program penyaluran zakat secara produktif yang mana model ini dilakukan melalui program bantuan modal, pendidikan gratis dalam bentuk beasiswa dan sebagainya (Mustarin, 2017).

Berdasarkan penelitian yang dilakukan oleh Ali, Amalia, dan Ayyubi, (2016) penyampaian zakat secara produktif seperti pemberian modal usaha kepada mustahiq lebih mampu mengurangi kemiskinan dan memberikan kesejahteraan kepada mustahiq. Dikarenakan melalui pemberian uang modal tersebut mustahiq dapat mengembangkan usaha yang dimiliki untuk memenuhi kebutuhan hidup di masa mendatang dan lebih sejahtera serta bahagia. Hal ini sejalan dengan pernyataan Myers (dalam Wulandari dan Widyastuti, 2014) bahwa kebahagiaan dirasakan melalui kesejahteraan secara finansial. Disinilah peneliti tertarik untuk mengetahui apakah ada perbedaan pemberian zakat berupa beasiswa sekolah gratis, atau kesehatan akan memberikan kebahagiaan terhadap mustahiq, seperti halnya mustahiq yang menerima modal uang secara langsung.

Setiap manusia ingin merasakan kebahagian, termasuk mustahik. Hal ini sangat wajar karena kebahagiaan merupakan salah satu fitrah manusia dalam kehidupan (Sentanu, 2009). Kebahagiaan bukanlah sesuatu yang diberikan secara cuma-cuma, 
akan tetapi merupakan hasil dari ikhtiar manusia memenuhi berbagai kebutuhan hidup yang dipersepsikan akan menghantarkannya pada kebahagiaan.

Kebahagiaan hidup ini ditandai dengan lebih banyaknya afek positif yang dirasakan individu dari pada afek negatif. Afek positif yang dirasakan akan mengarahkan pada hidup yang lebih baik. Hal ini terlihat dari bagaimana seseorang menciptakan hubungan yang lebih baik, semakin produktif, umur menjadi lebih panjang, kesehatan semakin lebih baik, kreativitas dan kemampuan pemecahan masalah serta membuat keputusan mengenai rencana hidup yang lebih baik (Carr, 2011).

Para ahli mencoba menjelaskan bagaimana manusia dapat meraih kebahagiaan. Frankl (dalam Bastamam, 2007) menyatakan bahwa keberhasilan manusia dalam memenuhi keinginannya untuk hidup bermakna (will to meaning) akan menghantarkannya pada kebahagiaan. Manusia yang berhasil mencapai hidup bermakna akan memperoleh kebahagiaan. Sebaliknya mereka yang tidak berhasil memenuhi motivasi ini akan mengalami kekecewaan, kehampaan hidup, merasakan hidup yang tidak bermakna, dan akhirnya tidak bahagia. Senada dengan hal tersebut, Lyubomirsky (2005) menguraikan lebih lanjut faktor-faktor yang mendatangkan kebahagiaan. Menurutnya ada tiga faktor yang membuat manusia merasa bahagia, yaitu faktor genetik (set range), keadaan atau situasi yang berubah-ubah dari waktu ke waktu (circumstances) dan hal-hal yang dikendalikan atau kegiatan yang disengaja (voluntary activities). Senada dengan pendapat tersebut, Eddington dan Shuman (2005) juga berpendapat bahwa domain kehidupan yang menjadi sumber kebahagiaan, adalah diri sendiri, keluarga, waktu, kesehatan, keuangan dan pekerjaan.

Berdasarkan uraian di atas tampak bahwa kebahagiaan merupakan sesuatu yang sifatnya subjektif. Setiap orang memiliki pendapat yang berbeda tentang sumber kebahagian hidup mereka. Terdapat beragam aktivitas dan situasi yang dapat membuat orang bahagia. Lyumbomirsky, Sheldon \& Schkade (2005) menggambarkan situasi ini dengan subjective happiness, yaitu penilaian subjektif dan global dalam menilai diri sebagai orang yang bahagia atau tidak. Beberapa riset terdahulu menekankan aspek ekonomi dan penghasilan sebagai sumber kebahagiaan manusia. Putri (2009) menemukan bahwa individu yang bekerja lebih bahagia dibandingkan dengan individu yang tidak bekerja. Selain itu, memiliki tingkat ekonomi yang tinggi (kaya) memungkin individu untuk merasakan hidup yang menyenangkan dan memiliki peristiwa hidup dengan sedikit stres, karena dapat melakukan hal yang diinginkan seperti, membantu orang lain, berbelanja dan rekreasi (Diener dan Biswa-Diener, 2011).

Akan tetapi hasil penelitian ini memiliki kondisi berbeda dengan temuan Easterlin (1974) yang menemukan adanya sebuah paradox of happiness, yaitu suatu situasi dimana peningkatan pendapatan tidak selalu mampu meningkatkan kebahagiaan seseorang. Jika awalnya pendapatan berjalan linear dengan kebahagiaan, namun pada titik tertentu, relasi keduanya mencapai titik jenuh, sehingga hubungan pendapatan dan kebahagiaan menurut hingga hilang sama sekali. Hal ini mengindikasikan bahwa ada faktor selain pendapatan (material) yang mempengaruhi kebagahiaan. 
Di Indonesia sendiri penelitian tentang kebahagiaan juga menunjukkan temuan yang tidak jauh berbeda dengan temuan Easterlin di atas. Wenas, Opod, \& Pali (2015) meneliti masyarakat dengan tingkat sosial ekonomi dan pendidikan yang beragam di Kota Bitung, Manado menemukan bahwa terdapat hubungan yang rendah antara kebahagiaan dengan status sosial ekonomi. Penelitian lainnya dilakukan oleh Wibowo (2015) untuk menguji indikator kebahagiaan dan kesejahteraan masyarakat di setiap provinsi di Indonesia. Hasil pengujian terhadap variabel nilai indeks kebahagiaan dengan variabel kemiskinan, ketimpangan pendapatan dan pendapatan per kapita menunjukkan hasil yang cukup menarik. Ketiga variabel tersebut tidak berpengaruh signifikan terhadap tingkat kebahagiaan masyarakat. Hal ini berarti bahwa kontribusi faktor sosial ekonomi terhadap kebahagiaan tidak cukup signifikan.

Berdasarkan hasil survei World Happiness Report yang diterbitkan oleh UN SDSN (United Nation Sustainable Development Solutions Network) ditemukan bahwa tingkat kebahagian masyarakat Indonesia mengalami penurunan dari 2015-2018. Tahun 2015, Indonesia masuk dalam peringkat 74, tahun 2016 peringkat Indonesia menurun menjadi peringkat 79. Sedangkan tahun 2018, peringkat Indonesia semakin menurun dan berada pada peringkat 96 (CNNIndonesia.com). Indikator yang digunakan pada survei tersebut meliputi PDB (Product Domestic Bruto) per kapita, angka harapan hidup, bantuan sosial, kebebasan sosial, persepsi korupsi dan kemurahan hati.

Hasil yang berbeda diperoleh dari data Badan Pusat Statistik (BPS). Menurut survei BPS, Indeks kebahagiaan masyarakat Indonesia mengalami peningkatan dari tahun 2014 dan 2017. Pada tahun 2014 indeks kebahagiaan masyarakat sebesar 68,28 dan meningkat menjadi 70,69 pada tahun 2017. Survei ini menggunakan tiga dimensi untuk mengukur kebahagiaan yaitu kepuasan hidup, perasaan dan makna hidup.

Adanya perbedaan hasil survei dari dua lembaga survei tentang tingkat kebahagian masyarakat Indonesia dan faktor sosial ekonomi yang tidak signifikan mempengaruhi kebahagiaan, maka peneliti tertarik untuk melihat bagaimana gambaran kebahagian pada masyarakat yang berhak menerima zakat (mustahik) khususnya di Pekanbaru.

\section{Kebahagiaan}

Kebahagiaan adalah keadaaan sejahtera dan kepuasan hati, yaitu kepuasan yang menyenangkan dan timbul bila kebutuhan dan harapan tertentu individu terpenuhi (Hurlock, 1997). Menurut Seligman (2005), kebahagiaan hidup merupakan konsep yang mengacu pada emosi positif yang dirasakan individu serta aktivitas-aktivitas positif yang disukai oleh individu tersebut. Kebahagiaan hidup ini ditandai dengan lebih banyaknya afek positif yang dirasakan individu dari pada afek negatif.

Veenhoven (2005) menyatakan bahwa kebahagiaan adalah perasaan suka, senang, gembira yang dirasakan oleh individu dan sumber penyebab munculnya kebahagiaan bagi setiap individu berbeda-beda. Dengan kata lain, hanya orang-orang yang bersangkutan yang dapat mengatakan apakah mereka bahagia atau tidak bahagia dengan kehidupan yang mereka jalani. Menurut Khavari (2006) kebahagiaan terasa 
tidak hanya ketika mendapatkan apa yang kita inginkan, tetapi juga ketika kita menginginkan apa yang telah kita dapatkan. Basya (2007) mengungkapkan bahwa kebahagiaan merupakan suatu objek yang terus dicari manusia di setiap masa dan tempat. Sarana untuk mencapainya berbeda-beda antara satu orang dengan orang lain. Perbedaan itu sesuai dengan kepribadian masing-masing manusia, kecenderungankecenderungan, lingkungan-lingkungan dan kondisi-kondisi yang spesifik.

Menurut Al-Qarni (dalam Arif, 2004) kebahagiaan adalah sesuatu yang manusiawi, dirasakan individu yang bersifat instrinsik dan hanya dapat dirasakan tetapi tidak dapat dilihat oleh mata, tidak dapat diukur dengan harga, tidak dapat dibatasi oleh harta tetapi hanya dapat dirasakan oleh perasaan individu itu sendiri. Kebahagiaan adalah perasaan senang dan tenteram karena hati sehat dan berfungsi dengan baik. Kebahagiaan juga didefinisikan sebagai keadaan psikologis positif yang ditandai dengan tingginya derajat kepuasan hidup, afek positif, dan rendahnya derajat afek negatif (Carr, 2004). Menurut Diener, Scollon dan Lucas (2003) istilah subjective well-being merupakan istilah ilmiah dari happiness (kebahagiaan). Istilah ini lebih dipilih untuk digunakan oleh para ilmuwan. Subjective well-being atau kesejahteraan subjektif merupakan gabungan dari kepuasan hidup dan keseimbangan afek positif serta afek negatif (Lyubomirsky, Tkach, Dimatteo, 2006).

Berdasarkan uraian di atas, maka dapat disimpulkan bahwa kebahagiaan merupakan kondisi perasaan di dalam diri seseorang sebagai respon afeksi terhadap berbagai pengalaman kehidupan dan adanya kepuasan hidup. Individu yang bahagia ditandai oleh lebih kuatnya afeksi positif daripada afeksi negatif, serta adanya proses kognitif dalam mengevaluasi kejadian yang terjadi pada kehidupan.

\section{Aspek Kebahagiaan}

Aspek kebahagiaan terdiri dari dua bagian yaitu adanya situasi dan keadaan pikiran seseorang. Griffin( 2004) berpendapat bahwa suasana hati, sikap dan perasaan adalah satu bagian dari memahami sebuah kata kebahagiaan. Dan pemahaman yang lainnya berhubungan dengan kualitas kehidupan seseorang. Yang paling terpenting dari sebuah kebahagiaan adalah kepuasan hidup yang merupakan keadaan emosional yang dapat memberikan rasa puas, akan tetapi setiap individu mempunyai proses yang berbeda. Menurut Lucas, Diener dan Suh (2003) untuk pengukuran kepuasan hidup harus memenuhi kriteria validitas afektif dari kesejahteraan subjektif dan dapat mengidentifikasi antara emosi positif dan negatif.

Diener, Lucas dan Suh (2003) menyatakan bahwa kegembiraan merupakan aspek afektif dan kepuasan merupakan aspek kognitif. Aspek afektif tersebut terbagi menjadi dua komponen yang saling bebas yaitu afek positif dan afek negatif. Selanjutnya evaluasi kognitif digunakan untuk saling bergantung pada kepuasan di dalam variasi dominan, seperti pada keluarga atau aturan kerja dan pengalamanpengalaman kepuasan lainnya (Wahyuni, 2010).

Argyle, Martin dan Crossland (2002) menguraikan komponen kebahagiaan sebagai berikut : 
a. Kepuasan hidup

Kepuasan hidup ditandai dengan memiliki semangat hidup dan kemampuan untuk menyesuaikan berbagai perubahan kondisi. Kepuasan hidup meliputi merasa puas dalam hidup, merasakan bahwa hidup berharga, senang dengan diri, merasakan kehidupan yang baik, tertarik pada orang lain, menemukan hal yang menarik dalam hidup, ramah mada orang lain dan memiliki arti dan makna dalam hidup.

b. Gembira

Gembira ditandai dengan merasakan kesenangan akan sesuatu yang telah dijalani dalam hidup. Terdiri dari merasa senang, optimis, memiliki pengalaman yang menyenangkan, dapat mengatur waktu dengan baik, bersenang-senang dengan orang lain, merasa bahwa dunia itu indah, dan menemukan hal yang menarik dalam hidup.

c. Harga diri yang positif

Harga diri yang positif ditandai dengan penilaian terhadap diri yang positif dan menghargai akan kekurangan diri. Terdiri dari memiliki pengaruh yang baik, bersemangat, merasa sehat, memiliki keterlibatan dalam komitmen serta terlihat menarik.

d. Ketenangan

Tergambar dari tercapainya keinginan, memiliki mental yang kuat, dan memiliki kenangan yang indah dalam hidup.

e. Kontrol

Orang yang bahagia ditandai dengan adanya kontrol diri dalam hidupnya. Terdiri dari tidak berlebihan jika bergembira, mudah membuat keputusan dan dapat melakukan banyak hal.

f. Efikasi

Efikasi merupakan terwujudnya keinginan dan harapan seseorang seperti tercapainya keinginan

\section{Metode}

\section{Desain dan Sampel}

Desain penelitian yang digunakan dalam penelitian ini adalah penelitian kuantitatif dengan Teknik deskriptif frekuensi. Populasi dalam penelitian ini meliputi mustahik zakat yang ada di wilayah Kota Pekanbaru. Sampel penelitian berjumlah 180 orang dengan pengambilan menggunakan teknik purposive random sampling. Adapun kriteria adalah sebagai berikut:

1. Mustahik zakat yang terdaftar di lembaga amil zakat pekanbaru

2. Mengikuti program pemberdayaan yang dilakukan oleh lembaga amil zakat

3. subjek tergolong ke dalam usia remaja-dewasa

Alat Ukur. Alat ukur kebahagiaan yang digunakan dalam penelitian ini modifikasi dari Oxford Happiness Questionnaire (OHQ). OHQ merupakan skala yang dikembangkan 
oleh Argyle, Martin \& Crossland, mengungkap aspek happiness meliputi life satisfaction, joy, self esteem, calm, control dan efficacy.

Teknik Analisa Data. Data hasil penelitian dianalisa dengan menggunakan Anova.

\section{Hasil}

Dari hasil Annova diperoleh nilai $\mathrm{F}=0.407$ dan signifikan $\mathrm{p}=0.666(\mathrm{p}>0.05)$, hal ini berarti bahwa tidak terdapat perbedaan kebahagiaan mustahik berdasarkan bentuk bantuan yang diterima. Artinya bahwa kebahagiaan mustahik yang menerima bantuan dalam bentuk pendidikan tidak berbeda dengan kebahagiaan mustahik yang menerima bantuan dalam bentuk kesehatan maupun ekonomi. Selain itu dilakukan juga analisa crosstabulation untuk mengetahui tingkat kebahagiaan mustahik berdasarkan bentuk bantuan yang diterima.

Tabel 1

Tingkat Kebahagiaan Mustahik Berdasarkan Jenis Bantuan yang Diterima

\begin{tabular}{ccccccc}
\hline Bentuk & \multicolumn{3}{c}{ Kebahagiaan } & $\begin{array}{c}\text { Total } \\
\text { Bantuan }\end{array}$ \\
\cline { 2 - 5 } & $\begin{array}{c}\text { Sangat } \\
\text { rendah }\end{array}$ & Rendah & Sedang & Tinggi & $\begin{array}{c}\text { Sangat } \\
\text { Total }\end{array}$ & Tinggi \\
Pendidikan & & 1 & 5 & 128 & 18 & 152 \\
Ekonomi & & & 2 & 18 & 1 & 21 \\
Kesehatan & & & 7 & & 180 \\
\hline Total & & & & & \\
\hline
\end{tabular}

Dari tabel 1 di atas diketahui bahwa bantuan yang paling banyak diterima oleh mustahik adalah bantuan dalam bentuk pendidikan yaitu sebanyak 152 orang dan paling sedikit adalah bantuan dalam bentuk kesehatan sebanyak 7 orang. Dari 152 orang mustahik yang memperoleh bantuan pendidikan, sebanyak 128 orang menunjukkan kebahagian yang berada pada kategori tinggi dan hanya 1 orang yang menunjukkan kebahagian pada kategori rendah. Untuk mustahik yang menerima bantuan dalam bentuk ekonomi berjumlah 21 orang. Terlihat bahwa tidak ada mustahik yang menunjukkan kebahagiaan pada kategoi rendah, 1 orang menunjukkan kebahagiaan berada pada kategori sangat tinggi, 18 orang menunjukkan kebahagiaan berada pada kategori tinggi dan 2 orang berada pada kategori sedang. Sedangkah untuk bantuan dalam bentuk kesehatan, diterima oleh 7 orang mustahik dan semuanya menunjukkan kebahagiaan berada pada kategori tinggi.

Selanjutnya, kondisi kebahagiaan mustahik laki-laki dan perempuan sebagaimana terdapat pada tabel 2 dan 3. Berdasarkan data pada tabel 2 di atas dapat disimpulkan bahwa kebahagiaan mustahik laki-laki dan perempuan relatif sama. Hal ini tampak pada mean yang tidak jauh berbeda pada kedua kelompok. 
Tabel 2

Gambaran Kebahagiaan Mustahik berdasarkan Jenis Kelamin

\begin{tabular}{cccccc}
\hline & Jenis Kelamin & $\mathrm{N}$ & Mean & Std. Deviation & Std. Error Mean \\
\hline \multirow{2}{*}{ Kebahagiaan } & Laki-laki & 65 & 53.06 & 6.880 & .853 \\
\cline { 2 - 6 } & Perempuan & 115 & 53.55 & 5.863 & .547 \\
\hline
\end{tabular}

Tabel 3

Tingkat Kebahagiaan Mustahik Berdasarkan Jenis kelamin

\begin{tabular}{|c|c|c|c|c|c|c|}
\hline \multirow{2}{*}{$\begin{array}{c}\text { Jenis } \\
\text { kelamin }\end{array}$} & \multicolumn{5}{|c|}{ Kebahagiaan } & \multirow{2}{*}{$\begin{array}{l}\text { Total } \\
\text { Total }\end{array}$} \\
\hline & $\begin{array}{l}\text { Sangat } \\
\text { rendah }\end{array}$ & Rendah & Sedang & Tinggi & $\begin{array}{c}\text { Sangat } \\
\text { Tinggi }\end{array}$ & \\
\hline Laki-laki & & 1 & 2 & 56 & 6 & 65 \\
\hline Perempuan & & & 5 & 97 & 13 & 115 \\
\hline Total & & & & & & 180 \\
\hline
\end{tabular}

Dari tabel 3 di atas diperoleh hasil bahwa 13 orang mustahik perempuan menunjukkan kebahagiaan pada kategori sangat tinggi, 97 orang menunjukkan kebahagian pada kategori tinggi, 5 orang menunjukkan kebahagiaan pada kategori sedang. Sedangkan pada mustahik laki-laki, 6 orang menunjukkan kebahagian pada kategori sangat tinggi, 56 orang menunjukkan kebahagiaan pada kategori tinggi, 2 orang pada kategori sedang dan 1 orang menunjukkan kebahagian pada kategori rendah. Dengan demikian dapat disimpulkan bahwa tingkat kebahagiaan mustahik laki-laki dan perempuan tergolong tinggi.

Gambaran kebahagiaan mustahik berdasarkan usia dapat dilihat pada tabel 4 dan 5 berikut :

Tabel 4

Hasil Uji Anova Kebahagiaan Ditinjau dari Usia

\begin{tabular}{crrrrr}
\hline Kebahagiaan & \multicolumn{1}{c}{} & & & \\
\cline { 2 - 5 } & \multicolumn{1}{c}{ Sum of Squares } & df & Mean Square & \multicolumn{1}{c}{ F } & \multicolumn{1}{c}{ Sig. } \\
\hline Between Groups & .517 & 2 & .259 & .007 & .993 \\
Within Groups & 6957.544 & 177 & 39.308 & & \\
Total & 6958.061 & 179 & & & \\
\hline
\end{tabular}

Dari table 4 di atas, dapat dilihat bahwa nilai signifikansi dari uji Anova sebesar 0.993. Hal ini berarti bahwa tidak terdapat perbedaan kebagahiaan pada mustahik zakat ditinjau dari Usia.

Dari table 5 di atas, dapat dilihat bahwa terdapat tiga kelompok usia musathik zakat. Dimana terlihat bahwa tidak ada perbedaan kebahagian pada ketiga kelompok usia subjek dengan nilai signifikansi 0.993 ( $\mathrm{p}>0.05)$. 
Tabel 5

Gambaran Tingkat Kebahagiaan Berdasarkan Usia

\begin{tabular}{lrrr}
\hline & & \multicolumn{2}{c}{ Subset for alpha $=\mathbf{0 . 0 5}$} \\
\cline { 3 - 4 } Usia & $\mathbf{N}$ & & $\mathbf{1}$ \\
\hline 760 & 2 & 53.00 \\
$40-60$ & 83 & 53.34 \\
$18-40$ & 95 & 53.41 \\
\hline Sig. & & .993 \\
\hline
\end{tabular}

\section{Pembahasan}

Dari hasil analisis di atas, didapat bahwa tidak ada perbedanaan kebahagiaan pada mustahik zakat berdasarkan jenis bantuan yang diterima. Hal ini berarti bahwa mustahik zakat yang menerima bantuan dalam bentuk pendidikan ekonomi dan kesehatan memiliki tingkat kebagahagiaan yang sama. Pada penelitian Sartika (2008) menemukan bahwa jumlah dana (zakat) yang disalurkan kepada mustahiq memiliki pengaruh yang besar terhadap pendapatan mereka, sehingga dengan bertambahnya pendapatan melalui zakat yang diberikan dapat memberikan perasaan bahagia. Bantuan yang diberikan oleh lembaga amil zakat dapat menjadi salah satu faktor penunjang kebahagiaan mustahik. Sebagaimana Diener, Ryff, Argyle, dkk (dalam Lyubomirsky, 2005) menyatakan bahwa dengan adanya dukungan sosial individu akan merasa bahagia.

Lembaga amil zakat memberikan bantuan dana dalam bentuk pendidikan, ekonomi dan kesehatan. Di samping bantuan dana, para mustahik juga mendapatkan kesempatan untuk bertemu dengan mustahik lainnya, dan mendapatkan materi-materi keagamaan secara berkala. Hal ini membuka peluang untuk saling bertukar pengalaman dan saling menguatkan antara satu sama lain.

Melalui bantuan ekonomi, para mustahik juga mendapatkan pembekalan teknis tentang wirausaha dan manajemennya. Hal ini dapat meningkatkan keyakinan mustahik dalam menyiasati kesulitan ekonomi yang dihadapi. Seligman (2005) menyatakan bahwa interaksi dengan orang lain, dan religiusitas dapat membuat orang bahagia. Senada dengan temuan Colon-Baco (2010) dalam studinya bahwa interaksi sosial dan dukungan positif yang diperoleh dari teman, keluarga, dan lingkungan akan memberikan dampak positif bagi subjective well-being.

Tidak adanya perbedaan kebahagiaan pada mustahik zakat juga terlihat pada variabel lainnya, yaitu varibel jenis kelamin. Hal ini berarti bahwa baik mustahik lakilaki maupun perempuan sama-sama merasakan kebahagiaan atas bantuan zakat yang mereka terima. Begitupula pada variabel usia, dimana mustahik yang berada pada rentang usia remaja akhir, dewasa awal maupun madya memiliki tingkat kebahagiaan yang relatif sama. Hal ini senada dengan yang ditemukan oleh Qudsyi, Novitasari, 
Fakhrunnisak, Ambarito, dan Yudhani (2015) bahwa tidak terdapat perbedaan kepuasan hidup berdasarkan jenis kelamin dan usia.

Meskipun dari hasil di atas tidak terlihat perbedaan, namun pada dasarnya kebahagiaan merupakan hal yang bersifat subjektif, yang dapat dirasakan oleh setiap individu dari berbagai latar belakang dan kondisi. Carr (2004) mengidentifikasi faktorfaktor yang mempengaruhi kebahagiaan dan menemukan bahwa perbedaan pada setiap individu mempengaruhi kemampuannya untuk mencapai kebahagiaan. Perbedaan ini dapat disebabkan oleh perbedaan kepribadian dan lingkungan yang menyediakan kesempatan individu untuk mencapai kebahagiaan yang dibutuhkan atau diinginkan.

Seligman (2005) menguraikan bahwa perasaan positif dapat mendorong individu untuk bertindak secara positif, seperti membangun relasi yang baik dengan orang lain, memiliki pikiran dan semangat optimisme, memiliki rohani yang sehat, keluarga yang harmonis, memiliki semangat saling tolong menolong, dan menghormati orang lain. Unsur-unsur inilah yang membuat seseorang memiliki kebahagiaan sejati. Begitu pula pada para mustahik zakat.

Dari hasil penelitian ini, dapat dikatakan bahwa para mustahik sudah mampu mencapai kebahagiaan yang diimpikan semua orang menurut versi mereka. Sebagaimana hasil penelitian Wenas, Opod, \& Pali (2015) menemukan hal yang sama bahwa terdapat hubungan yang rendah antara status sosial ekonomi dengan kebahagiaan pada masyarakat di kelurahan Aertembag II kota Bitung. Hal ini bermakna bahwa kebahagiaan tidak selamanya ditentukan oleh status sosial ekonomi, meskipun pendapatan menjadi salah satu indikator kebahagiaan individu. Dengan kata lain kebahagiaan bukan di ukur dengan banyaknya materi yang dimiliki.

Setiap individu akan dapat mengembangkan kebahagiaan dalam hidupnya jika mampu mempertahankan semangat hidup dan kemampuannya untuk menyesuaikan diri dengan berbagai perubahan kondisi. Hal ini meliputi merasa puas dalam hidup, merasakan bahwa hidup berharga, senang dengan diri, merasakan kehidupan yang baik, tertarik pada orang lain, menemukan hal yang menarik dalam hidup, ramah pada orang lain dan memiliki arti dan makna dalam hidup. Emosi positif seperti gembira, optimis, dan ketenangan yang berusaha untuk diciptakan individu dalam kehidupannya turut menyokong kebahagiaan yang dirasakan individu terhadap diri dan kehidupannya. Dengan demikian terbangun harga diri yang lebih positif, memandang bahwa kehidupan dan kebahagiaan tergantung pada persepsi individu sendiri dan keyakinannya untuk mewujudkannya (Argyle, Martin dan Crossland, 2002).

\section{Kesimpulan}

Tidak terdapat perbedaan tingkat kebahagiaan para mustahik berdasarkan jenis bantuan yang diterima. Begitu pula halnya dengan jenis kelamin, usia, dan pekerjaan. Hal ini berarti bahwa para mustahik mempersepsikan kondisi kehidupannya secara positif sehingga mampu menerima dirinya, menunjukkan perasaan senang dan optimis, 
Psikobuletin: Buletin Ilmiah Psikologi

Vol. 2, No. 2, Mei, 2021 (132-143)

$e-I S S N: 2720-8958$

DOI : 10.24014/pib.v2i2.12624

memiliki harga diri yang baik, serta meyakini kemampuannya dalam menghadapi kehidupannya masing-masing.

\section{Referensi}

Arief, M. F., \& Habibah, N. (2015). Pengaruh Strategi Aktivitas (Bersyukur dan Optimis) terhadap Peningkatan Kebahagiaan pada Mahasiswa S1 Pendidikan Guru Sekolah Dasar. Seminar Psikologi \& Kemanusiaan, Sidoarjo: Fakultas Psikologi Universitas Muhammadiyah.

Azwar. S. (2017). Metode Penelitian Psikologi Edisi Kedua . Yogyakarta: Pustaka Pelajar.

Arikunto, S. (2011). Prosedur Penelitian Suatu Pendekatan Praktik. Jakarta: Rineka Cipta

Basya, S. H. (2007). Kamus Mini Hidup Bahagia. Jakarta: Cakrawala

Carr, A. (2011). Positive Psychology. London and New York : Touledge

Colon-Baco, E. (2010). The Stengtt of Religious Belief is Important to Subjective Well Being. Undergraduate Economic Review Vol. 6

Diener, Ed \& Biswas -Diener, Robert. (2001). Will Money Increase Subjective Well-Being.

Diener, E., Scollon, C.N., dan Lucas, R.E. (2003). The evolving concept of subjective well-being: the multifaceted nature of happiness. Advances in Cel Aging and Gerontology, 15,187-219.

Diener, E., E. M. Suh, R. E. Lucas, dan H. L Smith. (1999). Subjective wellbeing: Three decades of progress. Psychological Bulletin. 125: 276- 302.

Easterlin, R. A. (1974). Does Economic Growth Improve the Human Lot? In : Paul A. D., M. V. Reder (eds) Nations Households in Economic Growth: Essays in Honour of Moses Abramovitz. New York : Academic Press.

Eddington, N. dan Shuman, R. (2005). Subjective Well Being (Happiness).

http://www.texcpe.com/cpe/PDF/ca-happiness.pdf. Diakses pada 20Maret 2017.

Elzaky, J. (2015). Buku Pintar Mukjizat Kesehatan Ibadah. Jakarta : Zaman

Kementrian Agama Republik Indonesia. (2015). Pedoman Zakat 9 Seri. Jakarta :

Kemenag

Khavari, K. (2006). Menciptakan Kebahagiaan dalam Setiap Keadaan. Jakarta: Serambi Ilmu Semesta.

Lyubomirsky, S., Shedon, K M., dan Schkade, D. (2005). Pursuing Happiness: The Architecture of Sustainable Change." APA Review of General Psychology. 9(2),111-131.

Lyubomirsky, S., Tkach, C., \& Dimatteo, M. R. (2006). What Are the Differences 
Between Happiness and Self-Esteem. Social Indicators research. 78. 363-404.

Mustarin, B. (2009). Urgensi Pengelolaan Zakat Terhadap Peningkatan Perekonoian Masyarakat. Jurisprudentie. 4 (2) 83-95.

Putri. (2009). Kebahagiaan dan Kualitas Hidup Penduduk Jabodetabek (Studi Dewasa Muda Bekerja dan Tidak Bekerja). Skripsi: Universitas Indonesia.

Qudsyi, Novitasari, Fakhrunnisak, Ambarito, dan Yudhani. (2015). Kepuasan Hidup Orang Bekerja Ditinjau dari Faktor Pribadi, Pekerjaan, dan Pasangan. Conference paper Seminar Nasional UII 2015

Sartika, M. (2008). Pengaruh Pendayagunaan Zakat Produktif terhadap Pemberdayaan Mustahiq pada LAZ Yayasan Solo Peduli Surakarta. LaRiba Jurnal Ekonomi Islam Vol 2 (1)

Seligman, E. P, M. (2005). Authentic Happiness Menciptakan Kebahagiaan dengan Psikologi Positif. Bandung: Mizan.

Sentanu, E. (2009). Quantum ikhlas, teknologi aktivasi kekuatan hati. Jakarta : Elex Media Komputindo

Siregar, I. D. (2017). Anak Yatim Sebagai Mustahik Zakat di Kecamatan Sipirok Kabupaten tapanuli Selatan: Suatu Kajian Sosiologi Hukum. Journal of Islamic Law, (1) $\quad 2, \quad 1-11 . \quad$ Retrieved from http://jurnal.uinsu.ac.id/index.php/attafahum/article/view/756

Urif, Z. A., Herwanto, T., Huzaini, M. (2018). Perilaku Mustahiq Dalam Memanfaatkan Dana Zakat Perspektif Ekonomi Islam. Jurnal Ekonomi dan Perbankan Syariah. 5 (1), 86-109.

Veenhoven R. 2000. Happiness Relative.https://personal.eur.nl/veenhoven/ Pub1980s/89f-full.pdf diakses 16 Maret 2017

Wenas, G.E., Opod, Henry., dan Pali, C. (2015). Hubungan kebahagiaan dan status sosial ekonomi keluarga di Kelurahan Artembaga II Kota Bitung. Jurnal eBiomedik (eBm). 3(1), 532-538

Wibowo, M. Ghafur. (2016). Kebijakan Pembangunan Nasional : dari Pertumbuhan (Growth) Menuju Kebahagiaan (Happiness). Jurnal Ilmu Syari'ah dan Hukum. 50(1), 223-239

Wilson, W. P. (1997). Correlates of Avowed Happiness. Psychological Buletin No.67

Wulandari, S. \& Widyastuti, A. (2014). Faktor - Faktor Kebahagiaan Di Tempat Kerja. Jurnal Psikologi. (1) 1, 49-60. Retrieved from: https://media.neliti.com/. 